\author{
Witold Śmigielski \\ https://orcid.org/0000-0002-5239-2988 \\ Uniwersytet Łódzki \\ Wydział Ekonomiczno-Socjologiczny \\ Katedra Demografii \\ witold.smigielski@uni.lodz.pl
}

\title{
NADUMIERALNOŚĆ Z POWODU CHORÓB UKŁADU KRĄŻENIA JAKO CZYNNIK DEPOPULACYJNY ŁODZI I REGIONU
}

\begin{abstract}
Abstrakt: Choroby układu krążenia (ChUK) stanowią najczęstszą przyczynę zgonów zarówno w Polsce, jak i na terenie UE. Natężenie zgonów z powodu ChUK w województwie łódzkim należy do jednego z najwyższych w Polsce. Celem autora niniejszej pracy było porównanie poziomu umieralności z powodu ChUK w Łodzi i w regionie z poziomem ogólnokrajowym przy zniwelowaniu czynnika demograficznego. Wyniki przeprowadzonych analiz wskazały, że województwo łódzkie charakteryzuje się nadumieralnością z powodu ChUK, sięgającą średniorocznie blisko 1000 osób, przy tym wskazana niekorzystna sytuacja utrzymuje się już od kilkunastu lat.
\end{abstract}

Słowa kluczowe: choroby układu krążenia, umieralność, Łódź, województwo łódzkie.

\section{CARDIOVASCULAR OVERMORTALITY AS THE DEPOPULATION FACTOR OF CITY LODZ AND REGION}

Abstract: Cardiovascular diseases (CVD) are the leading cause of mortality in Poland and in the EU as well. Cardiovascular death rate in Lodzkie Voivodeship is one of the highest in Poland. The aim of this paper is to compare the level of CVD mortality in the city of Lodz and nearby region with the Polish national level after elimination of the age factor. The result of analysis indicates that Lodzkie Voivodeship is characterized by the overmortality caused by cardiovascular disease of about 1,000 people every year.

Keywords: cardiovascular disease, mortality, Lodz, Lodzkie Voivodeship.

\section{WSTĘP}

Na proces depopulacji mają wpływ dwa czynniki: ujemny przyrost naturalny oraz ujemne saldo migracji. Zagadnienia migracyjne regionu łódzkiego nie są tematem niniejszej pracy, jednak warto nadmienić, że szczegółowe analizy tego aspektu są w literaturze przedmiotu dokładnie opisane w cyklicznych publikacjach Kałuży-Kopias (zob. m.in. Kałuża-Kopias, 2015, 2016, 2017).

Z niepokjem należy odnotować, że - jak wskazują dane GUS - województwo lódzkie jako całość oraz samo miasto Łódź, będące jego stolicą, od lat niezmiennie cechują się ujemnym przyrostem naturalnym (wynoszącym od końca XX w. w Łodzi: w 1995 r.: -5393, 2000: -5530, 2005: -4674, 2010: $-3620,2015$ : $-4415,2017$ : -3782 , a w województwie łódzkim: w 1995 r.: $-6508,2000:-8492,2005:-8669$, 2010: -5695, 2015: -9012, 2017: -7390).

Ujemny przyrost naturalny jest efektem wyższej liczby zgonów niż urodzeń, dlatego na jego redukcję może wpływać wzrost liczby urodzeń lub redukcja liczby zgonów. Analiza zachowań rozrodczych mieszkanek województwa łódzkiego nie jest tematem niniejszego opracowania (m.in. Szukalski, 2015), zaś analizując poziom zgonów postanowiono ograniczyć się jedynie do analiz zgonów z powodu chorób układu krążenia (ChUK). Stanowią one bowiem najczęstszą przyczynę śmierci wśród rezydentów krajów Unii Europejskiej, odpowiadając za ponad $37 \%$ ich łącznej liczby zgonów. Warto w tym miejscu dodać, że - jak wskazują dane Eurostatu za 
rok 2014 - częściej niż co czwarty stwierdzony na terenie UE zgon był spowodowany chorobami nowotworowymi $(27,3 \%)$, a tym samym częściej niż co trzeci był wynikiem innej przyczyny niż ChUK lub nowotworu.

Celem autora niniejszego artykułu jest stwierdzenie, czy w Łodzi i w województwie łódzkim występuje problem nadumieralności z powodu ChUK. Odnosząc się do tego celu postawiono następujące hipotezy badawcze:

H1: Umieralność w województwie łódzkim z powodu ChUK kształtowała się w latach 2010-2014 na wyższym poziomie niż ogólnopolska średnia (przy uwzględnieniu struktury płci i wieku).

H2: Umieralność w Łodzi z powodu ChUK kształtowała się w latach 2010-2014 na wyższym poziomie niż ogólnopolska średnia wyznaczona dla miast (przy uwzględnieniu struktury płci oraz wieku).

Potwierdzenie wymienionych hipotez będzie oznaczało, że niekorzystne trendy epidemiologiczne Łodzi i regionu są dodatkowym czynnikiem wpływającym na depopulację wspomnianych obszarów, zaś w sensie praktycznym wskaże konieczność intensyfikacji działań władz regionalnych, mających na celu zwiększenie skuteczności promocji zachowań prozdrowotnych mieszkańców.

\section{PRZEMIANY UMIERALNOŚCI Z POWODU CHORÓB UKŁADU KRĄŻENIA W POLSCE W LATACH 2011-2014 NA TLE INNYCH PAŃSTW UNII EUROPEJSKIEJ}

Wśród 28 krajów Unii Europejskiej Polska znajdowała się w 2014 r. na 9. miejscu pod względem najwyższej częstości umieralności spowodowanej chorobami układu krążenia (wśród łącznej liczby zgonów). Warto przy tym zwrócić uwagę, że częstość zgonów z powodu ChUK w UE cechuje się pełzającą tendencją malejącą (rys. 1).

Choroby te stwierdzone w Polsce w 2014 r. odpowiadały za około cztery na dziewięć zgonów (45,1\%, podczas gdy nowotwory za $26,6 \%$ ). W UE w tym samym roku ChUK najczęściej były przyczynami zgonów w Bułgarii $(66,4 \%)$, Rumunii $(58,6 \%)$ i na Łotwie $(57,0 \%)$, Litwie $(56,5 \%)$ oraz w Estonii $(53,3 \%)$. W pozostałych krajach stanowily mniej niż połowę łącznej liczby zgonów w danym roku, przy czym najrzadziej były przyczyną śmierci w takich krajach, jak: Dania (24,3\%), Francja (25,0\%), Wielka Brytania $(27,2 \%)$, Holandia $(27,6 \%)$ i Belgia (28,9\%). Warto nadmienić, że w 2014 r. w pięciu krajach UE, tj. w Irlandii, Holandii, Wielkiej Brytanii, Francji i Danii, częstszą przyczyną zgonów niż ChUK były choroby nowotworowe (tab. 1).

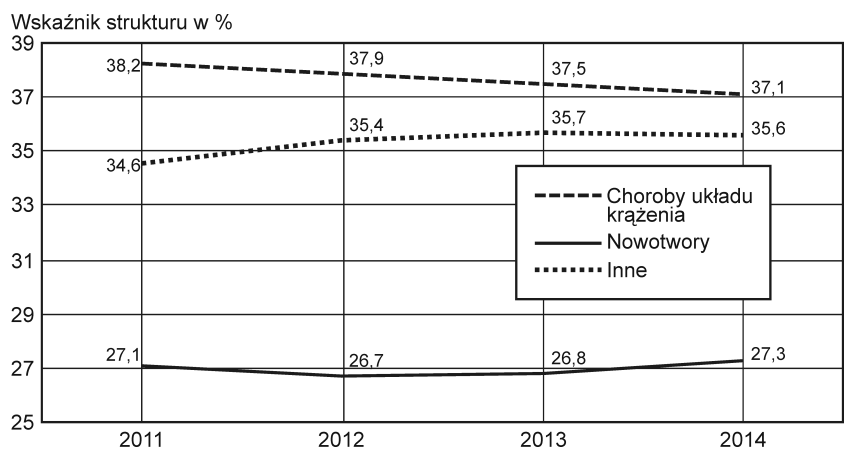

Rys. 1. Struktura głównych przyczyn zgonów w UE (EU28) w latach 2011-2014

Źródło: Eurostat

Tab. 1. Struktura głównych przyczyn zgonów w krajach Unii Europejskiej w 2014 r.

\begin{tabular}{|l|c|c|c|}
\hline \multirow{2}{*}{ Kraj } & \multicolumn{3}{|c|}{ Odsetek zgonów z powodu } \\
\cline { 2 - 4 } & ChUK & nowotworów & $\begin{array}{c}\text { innych } \\
\text { przyczyn }\end{array}$ \\
\hline UE (28) & 37,1 & 27,3 & 35,6 \\
\hline Bułgaria & 66,4 & 16,7 & 16,9 \\
\hline Rumunia & 58,6 & 19,9 & 21,5 \\
\hline Łotwa & 57,0 & 21,5 & 21,5 \\
\hline Litwa & 56,5 & 20,5 & 23,1 \\
\hline Estonia & 53,3 & 25,1 & 21,6 \\
\hline Węgry & 49,7 & 26,4 & 23,9 \\
\hline Chorwacja & 47,5 & 27,8 & 24,7 \\
\hline Czechy & 46,2 & 26,2 & 27,7 \\
\hline POLSKA & $\mathbf{4 5 , 1}$ & $\mathbf{2 6 , 6}$ & $\mathbf{2 8 , 3}$ \\
\hline Słowacja & 45,1 & 26,8 & 28,2 \\
\hline Austria & 43,0 & 27,3 & 29,7 \\
\hline Słowenia & 41,9 & 31,7 & 26,5 \\
\hline Grecja & 39,7 & 25,9 & 34,4 \\
\hline Niemcy & 38,9 & 26,6 & 34,5 \\
\hline Malta & 38,0 & 28,1 & 33,9 \\
\hline Finlandia & 37,6 & 23,5 & 39,0 \\
\hline Szwecja & 36,8 & 26,4 & 36,8 \\
\hline Włochy & 36,8 & 29,6 & 33,6 \\
\hline Cypr & 34,9 & 23,9 & 41,2 \\
\hline Luksemburg & 31,3 & 30,6 & 38,1 \\
\hline Portugalia & 30,7 & 25,4 & 43,9 \\
\hline Irlandia & 30,3 & 31,5 & 38,2 \\
\hline Hiszpania & 29,7 & 27,9 & 42,5 \\
\hline Belgia & 28,9 & 27,5 & 43,6 \\
\hline Holandia & 27,6 & 32,5 & 39,9 \\
\hline Wielka Brytania & 27,2 & 29,4 & 43,5 \\
\hline Francja & 25,0 & 29,8 & 45,2 \\
\hline Dania & 24,3 & 31,0 & 44,7 \\
\hline & & & \\
\hline & & & \\
\hline
\end{tabular}

Źródło: Eurostat. 
Częstość występowania zgonów z powodu ChUK jest silnie związana ze strukturą demograficzną danej populacji, a przede wszystkim z jej strukturą wiekową, dlatego na potrzeby analiz międzynarodowych lub regionalnych zamiast surowych wspólczynników zgonów prezentuje się zazwyczaj dane standaryzowane względem wieku. Wskazaną praktykę uzasadnia m.in. korelacja między natężeniem występowania zgonów w wyniku ChUK (na 100 tys. ludności) w poszczególnych województwach w Polsce a udziałem procentowym osób po 64. roku życia $\mathrm{w}$ populacji danego województwa (rys. 2), choć oczywiście przykłady tej zależności można by mnożyć.

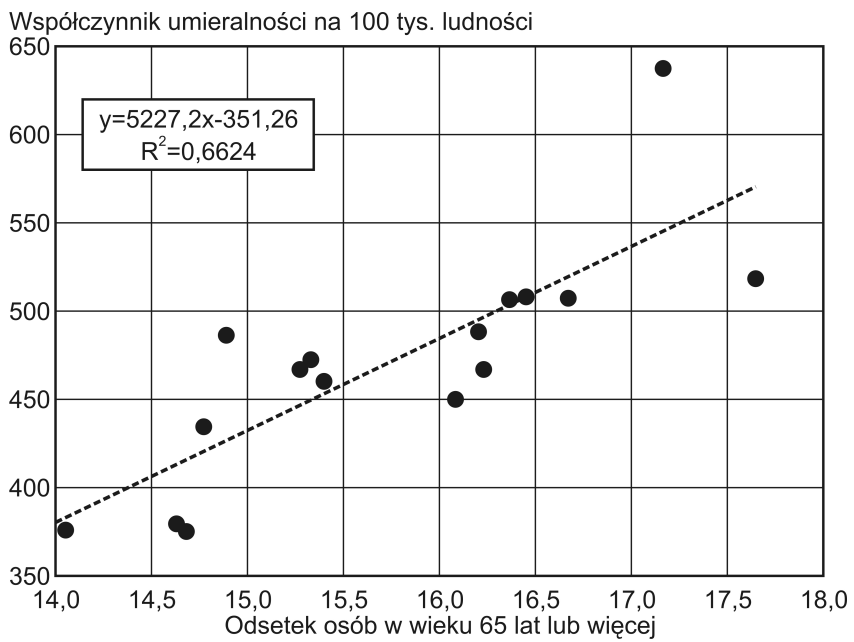

Rys. 2. Zależność między natężeniem występowania zgonów z powodu ChUK a odsetek osób po 64. roku życia w województwach w Polsce w 2015 r.

Źródło: opracowanie własne na podstawie danych GUS

Zestawienie standaryzowanych współczynników zgonu z powodu ChUK wśród krajów UE plasuje Polskę na odległym, 10. miejscu od końca, przy wyraźnie wyższej wysokości analizowanego współczynnika od sąsiadującej w zestawieniu Słowenii. Co więcej, standaryzowany współczynnik zgonów w wyniku ChUK w Polsce w 2015 r. był aż o 66\% wyższy niż średnia jego wartość dla krajów UE. Przedstawione dane wyraźnie ukazują występującą w Polsce nadumieralność z powodu ChUK w porównaniu do pozostałych krajów UE. Najkorzystniej pod względem analizowanego współczynnika zjawisko to kształtowało się we Francji, w Hiszpanii, Danii, Wielkiej Brytanii i Holandii, zaś najgorzej w Bułgarii, Rumunii i na Łotwie (por. rys. 3). Opisana sytuacja sprawia, że w takich krajach, jak Polska ważne jest dokładne analizowanie zmian poziomu umieralności na ChUK oraz wdrażanie niezbędnych programów promocji zdrowia (i konty- nuacja istniejących), których celem będzie poprawa stanu zdrowia Polek i Polaków, a w następstwie obniżenie współczynników zgonów i zmniejszenie dystansu dzielącego nasz kraj od europejskich standardów w tym zakresie (zob. m.in. Drygas, Słońska, 2015; Kwaśniewska, Drygas, 2015; Pająk, Jankowski, Wolfshaut-Wolak, 2015).

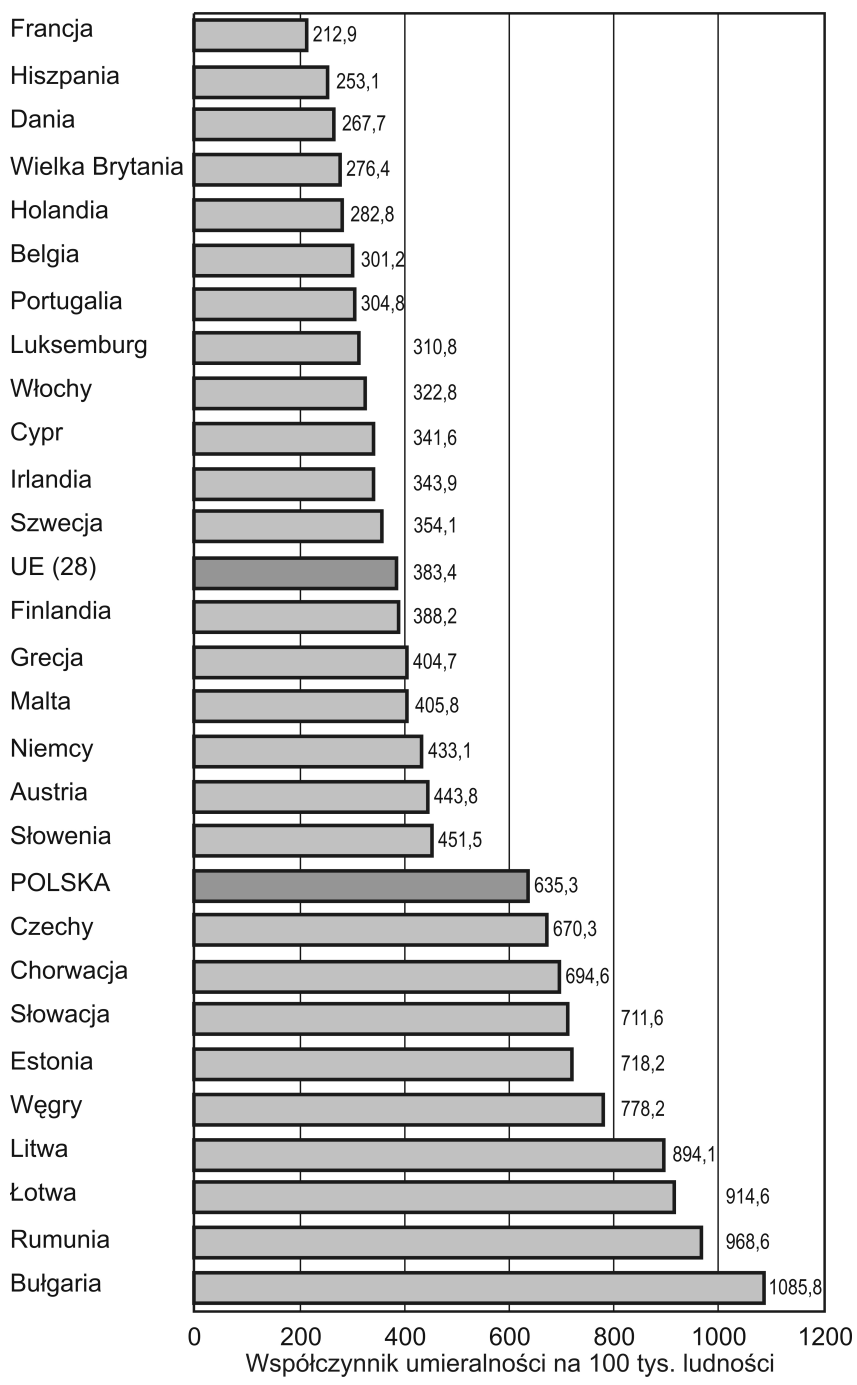

Rys. 3. Standaryzowane współczynniki zgonów w wyniku ChUK (na 100 tys. ludności) w krajach UE w 2015 r. Źródło: Eurostat

\section{UMIERALNOŚĆ Z POWODU CHORÓB UKŁADU KRĄŻENIA W POLSCE ZE SZCZEGÓLNYM UWZGLĘDNIENIEM ŁODZI I WOJEWÓDZTWA ŁÔDZKIEGO}

Podobnie jak w większości krajów UE choroby układu krążenia ${ }^{1}$, o czym już wspomniano, stanowią najczęstszą przyczynę zgonów ludności w Pol- 
sce (rys. 4), przy czym struktura przyczyn umieralności jest silnie determinowana przez wiek (por. rys. 5).

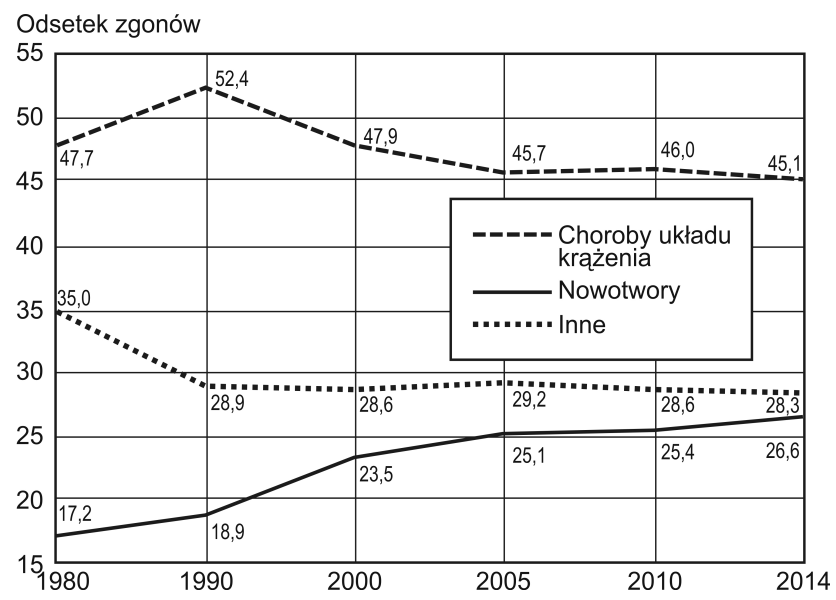

Rys. 4. Struktura przyczyn zgonów w Polsce w latach 1980-2015 Źródło: opracowanie własne na podstawie danych GUS

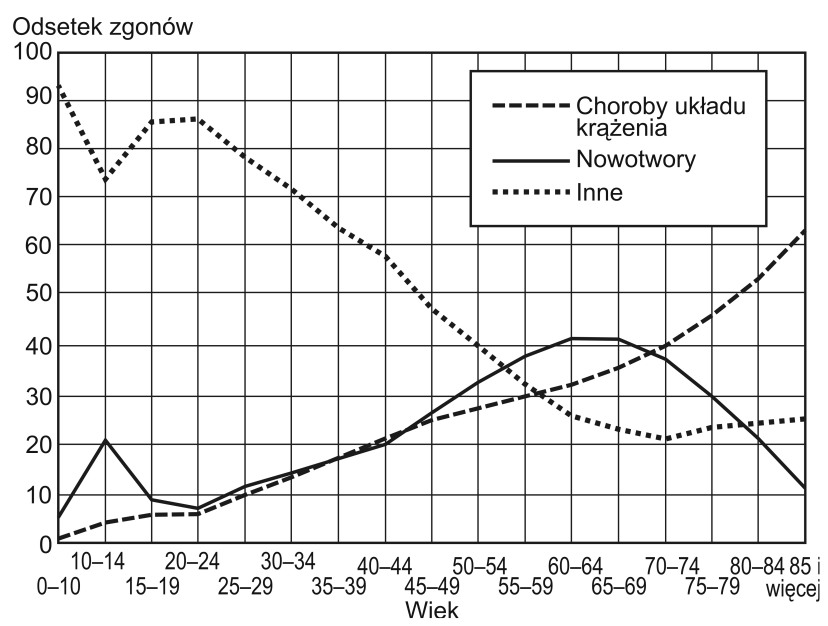

Rys. 5. Struktura przyczyn zgonów według grup wieku w Polsce w 2013 r.

Źródło: opracowanie własne na podstawie danych GUS

Analiza danych przedstawionych na rys. 5 wskazuje, że ChUK stanowiły dominującą przyczynę zgonów osób po 70. roku życia, a osoby z przedziału lat 45-70 najczęściej umierały na choroby nowotworowe. W przypadku zmarlych $\mathrm{w}$ wieku 20-44 lata ze zbliżoną częstością następują zgony $\mathrm{w}$ wyniku ChUK oraz chorób nowotworowych (por. także Wojtyniak, Stokwiszewski, 2015). Natężenie umieralności $\mathrm{z}$ powodu ChUK jest umiarkowanie silnie zróżnicowane terytorialnie, przy czym najniższymi wartościami cechują się województwa z północno-zachodniej części Polski (pomorskie, warmińsko-mazurskie i wielkopolskie), zaś najwyższymi województwa południowo-centralnej części kraju (świętokrzyskie, łódzkie i opolskie) (rys. 6). Warto przy tym zauważyć, że częstość zgonów z powodu
ChUK w województwie świętokrzyskim jest o około $70 \%$ większa niż w województwie pomorskim lub warmińsko-mazurskim (por. Wojtyniak, Zdrojewski, 2015).

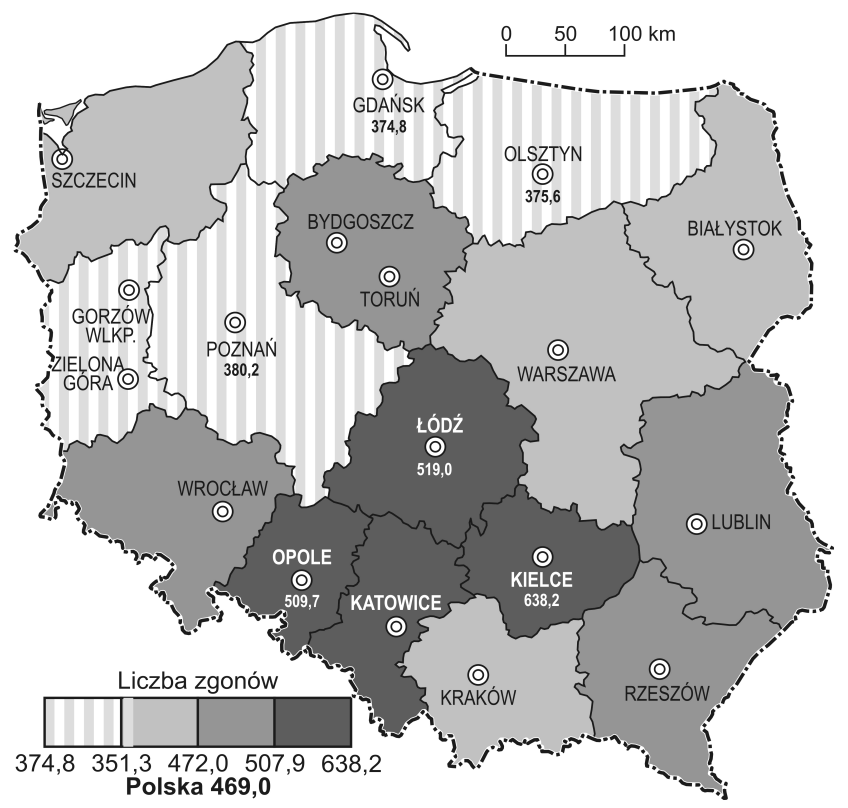

Rys. 6. Natężenie występowania zgonów z powodu ChUK w Polsce w 2015 r. według województw

Źródło: opracowanie własne na podstawie danych GUS

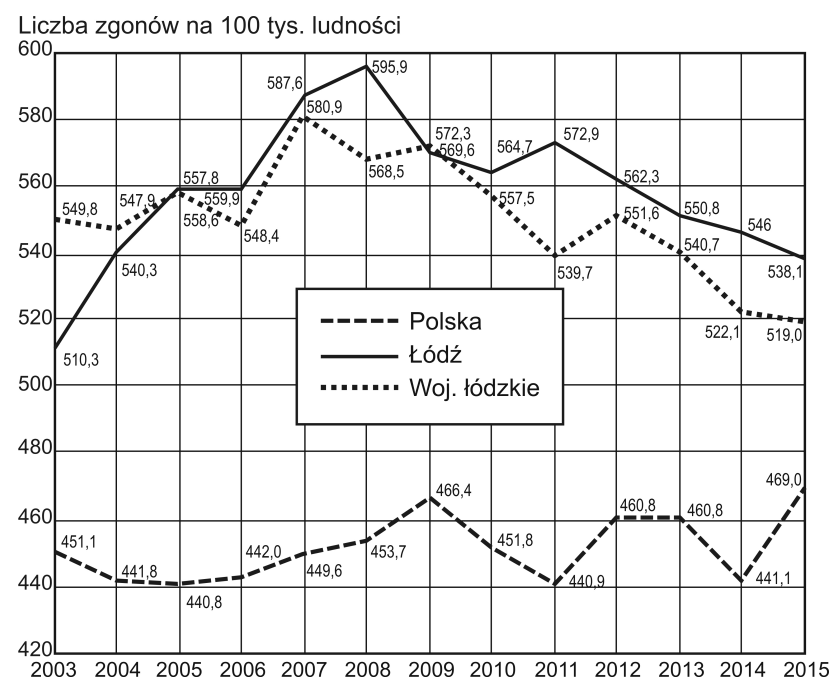

Rys. 7. Natężenie występowania zgonów (na 100 tys. ludności) w Łodzi i województwie łódzkim na tle wskaźników ogólnokrajowych w latach 2003-2015

Źródło: opracowanie własne na podstawie danych GUS

Analiza danych prezentowanych na rys. 6 wskazuje, że województwo łódzkie charakteryzuje się jednym z najwyższych współczynników zgonów spowodowanych ChUK, kształtującym się na poziomie znacznie powyżej średniej ogólnopolskiej, zaś w samej Łodzi od 2010 r. współczynnik zgonów w wyniku ChUK jest jeszcze wyższy niż dla woje- 
wództwa. Należy jednak w tym miejscu dodać, że natężenie umieralności od 2007 r. w przypadku województwa łódzkiego, a także od 2008 r. w Łodzi wykazuje tendencję malejącą (rys. 7) (zob. Cicha-Mikołajczyk, Piotrowski, Kurjata, Piwońska, Polakowski, 2016).

Na tle pozostałych powiatów województwa łódzkiego sytuacja w Łodzi pod względem umieralności z powodu chorób ChUK nie wygląda szczególnie niekorzystnie. W tym województwie (rys. 8) najniższym natężeniem występowania zgonów w wyniku przedmiotowych chorób wyróżniały się powiaty: bełchatowski, powiat-miasto Skierniewice oraz powiat łódzki wschodni, zaś najmniej korzystnie kształtowała się sytuacja pod tym względem w powiatach: kutnowskim, poddębickim, łęczyckim, skierniewickim, wieluńskim i łowickim, tzn. (z wyjątkiem powiatu wieluńskiego) w północnej części województwa łódzkiego (Przybylski, Szukalski, 2015). Niemniej jednak natężenie występowania zgonów z powodu ChUK w Łodzi, na tle innych wielkich miast w Polsce, przedstawia się już znacznie mniej korzystnie (rys. 9).

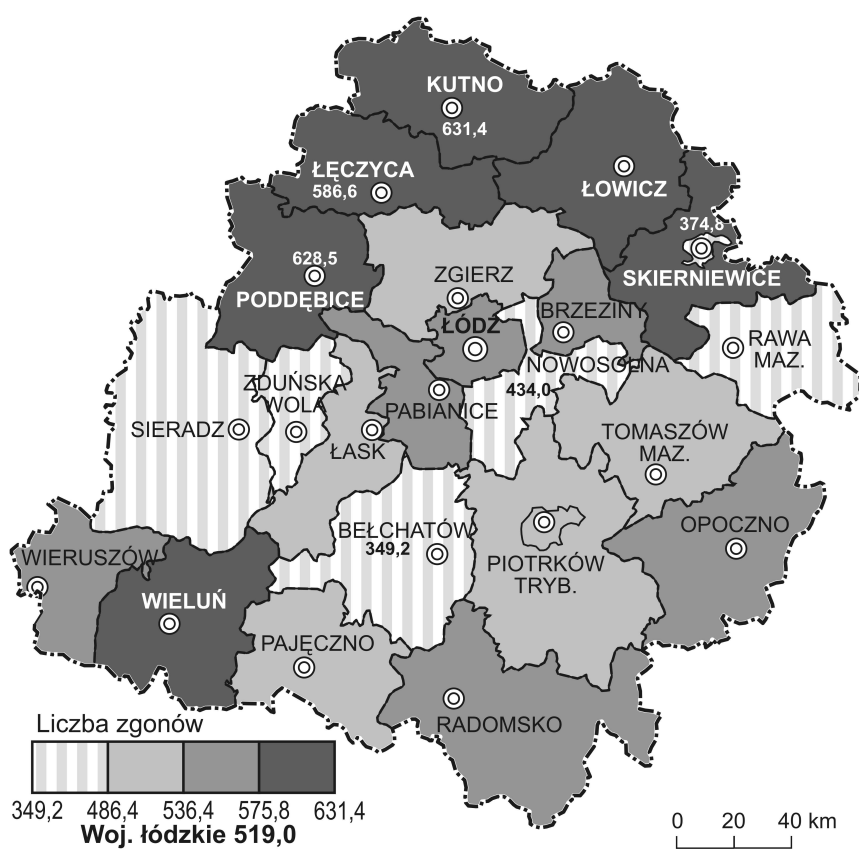

Rys. 8. Natężenie występowania zgonów z powodu ChUK w województwie łódzkim w 2015 r. według powiatów Źródło: opracowanie własne na podstawie danych GUS

Spośród polskich miast liczących powyżej 500 tys. mieszkańców najniższym natężeniem tego zjawiska do 2007 r. odznaczało się miasto stołeczne Warszawa, zaś od 2008 r. - Poznań. Przy tym w całym analizowanym okresie najwyższą częstością zgo- nów z powodu ChUK cechowała się Łódź (rys. 9; zob. także: Szukalski, 2012).

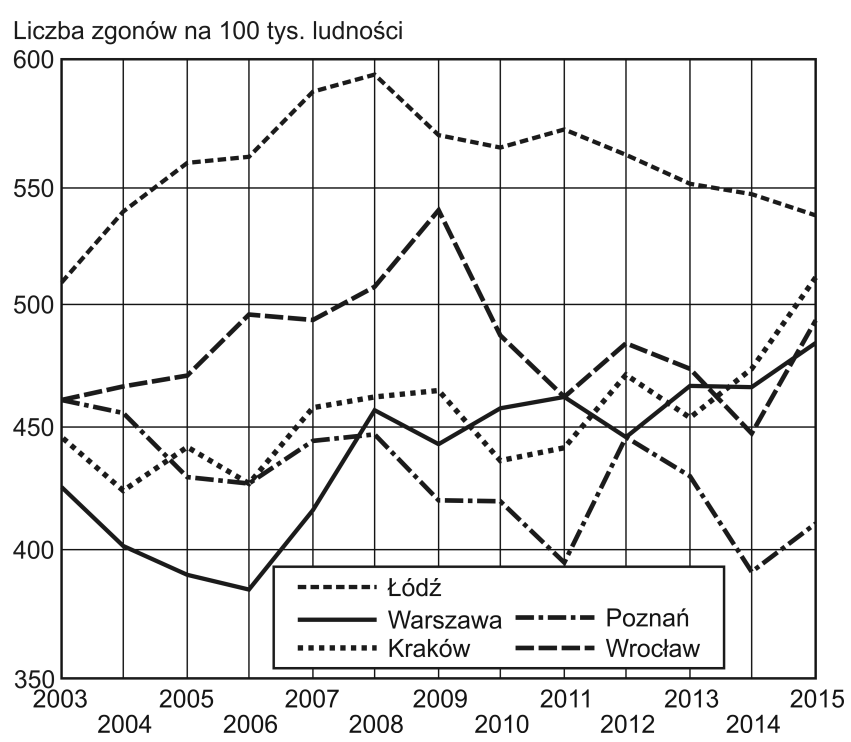

Rys. 9. Natężenie występowania zgonów (na 100 tys. ludności) w Łodzi na tle pozostałych wielkich miast w Polsce w latach 2003-2015

Źródło: opracowanie własne na podstawie danych GUS

\section{MATERIAŁ I METODY}

Zaprezentowane $\mathrm{w}$ poprzednim rozdziale dane mogą wskazywać, że Łódź i województwo łódzkie charakteryzuje nadumieralność z powodu ChUK (por. Pikala, Maniecka-Bryła, 2013), co - jeśli zostanie potwierdzone - niesie ze sobą określone skutki depopulacyjne dla Łodzi i województwa. Oczywiście takie analizy powinno się prowadzić $\mathrm{z}$ uwzględnieniem struktury demograficznej. Pewnym rozwiązaniem jest - wspomniana już w niniejszej pracy - powszechnie stosowana standaryzacja względem wieku lub też analizowanie tzw. cząstkowych współczynników zgonów (m.in. Szukalski, 2012). Zdecydowano jednak, by wskazane analizy dla Łodzi i województwa łódzkiego opracować w oparciu o teoretyczne liczebności zgonów z określonego powodu, oszacowane na podstawie struktury demograficznej i właściwych, przy założonych cechach demograficznych (wiek, płeć, miejsce zamieszkania), prawdopodobieństw zgonu. Punktem wyjścia do prowadzenia kolejnych analiz były następujące hipotezy badawcze:

1. Teoretyczną podstawą dalszych analiz było następujące zdefiniowanie prawdopodobieństwa wystąpienia zgonu: 


$$
P Z(C h U K)_{P, W(t)}=\frac{L Z(C h U K)_{P, W(t)}}{L L_{P, W(t)}}
$$

gdzie:

PZ(ChUK)P,W(t) - prawdopodobieństwo zgonu na ChUK osób danej płci i grupy wieku w roku $t$,

$L Z(C h U K)_{P, W(t)}$ - liczba zgonów z powodu ChUK osób danej płci i grupy wieku w roku $t$,

$L L_{P, W(t)}$ - liczba ludności danej płci i grupy wieku w roku $t$,

$P$ - płeć (mężczyzna, kobieta),

$W$ - grupa wieku $(0-4,5-9,10-14, \ldots, 75-79,80-84,85$ i więcej),

$t-\operatorname{rok}(2010,2011,2012,2013,2014)$.

2. Właściwe prawdopodobieństwa wystąpienia zgonów określane na potrzeby analiz dla badanego województwa były wyznaczane z wykorzystaniem danych ogólnopolskich, zaś dla Łodzi - na podstawie danych dla mieszkańców polskich miast. Następnie, opierając się na nich, określono teoretyczne liczebności zgonów w oparciu o wzór (2).

$T L Z(C h U K)_{\mathrm{OB}(t)}=T L Z\left(C h U K, \mathrm{~K}_{\mathrm{OB}(t)}+\mathrm{TLZ}\left(\mathrm{ChUK}, \mathrm{M}_{\mathrm{OB}(t)}\right.\right.$

gdzie:

TLZ (ChUK) $)_{B(t)}$ - teoretyczna liczba zgonów na ChUK na danym obszarze w roku $t$,

TLZ (ChUK, K) $\mathrm{OB(t)}$ - teoretyczna liczba zgonów kobiet na

ChUK na tym obszarze $\mathrm{w}$ roku $t$,

TLZ(ChUK, M) $)_{\mathrm{B}(t)}$ - teoretyczna liczba zgonów mężczyzn na ChUK na tym obszarze $\mathrm{w}$ roku $t$,

$O B$ - obszar (województwo łódzkie, Łódź),

$t$ - jak dla wzoru 1.

Przy tym:

a) $\operatorname{TLZ}(\operatorname{ChUK,} K)_{\mathrm{OB}(t)}=$

$$
\sum_{i=1}^{n} P Z\left[C h U K, K, T E R(t), w_{i}\right] \cdot \operatorname{LK}\left[O B(t), w_{i}\right]
$$

b) $T L Z(C h U K, M)_{O B(t)}=$

$$
\sum_{i=1}^{n} P Z\left[\operatorname{ChUK}, M, T E R(t), w_{i}\right] \cdot \operatorname{LM}\left[O B(t), w_{i}\right]
$$

gdzie:

PZ [ChUK, K, TER $\left.(t), w_{i}\right]$ - prawdopodobieństwo zgonu kobiet na ChUK, wyliczone na podstawie wzoru 1 na danym terenie $w$ roku $t$ dla grupy wiekowej $i$,

$L K\left[O B(t), w_{i}\right]$ - liczba kobiet na tym obszarze w roku $t$ w grupie wiekowej $i$,

PZ [ChUK, $\left.M, T E R(t), w_{i}\right]$ - prawdopodobieństwo zgonu mężczyzn na ChUK, wyliczone na podstawie wzoru 1 na danym terenie $w$ roku $t$ dla grupy wiekowej $i$,

$L K\left[O B(t), w_{i}\right]$ - liczba mężczyzn na tym obszarze $w$ roku $t \mathrm{w}$ grupie wiekowej $i$,

$T E R(t)^{2}$ - terytorium (Polska, miasta w Polsce), $O B(t)$ - jak dla wzoru 2.
Obliczone na podstawie przedstawionych wzorów prawdopodobieństwa wystąpienia zgonów dla kobiet i mężczyzn w Polsce, i następnie w polskich miastach, znajdują się $w$ tab. 2-5. Pozwoliło to na zestawienie, po uwzględnieniu struktury wiekowo-płciowej populacji w Łodzi i województwie łódzkim, empirycznej i teoretycznej liczby zgonów z powodu ChUK w analizowanych latach (rys. 10 i 11).

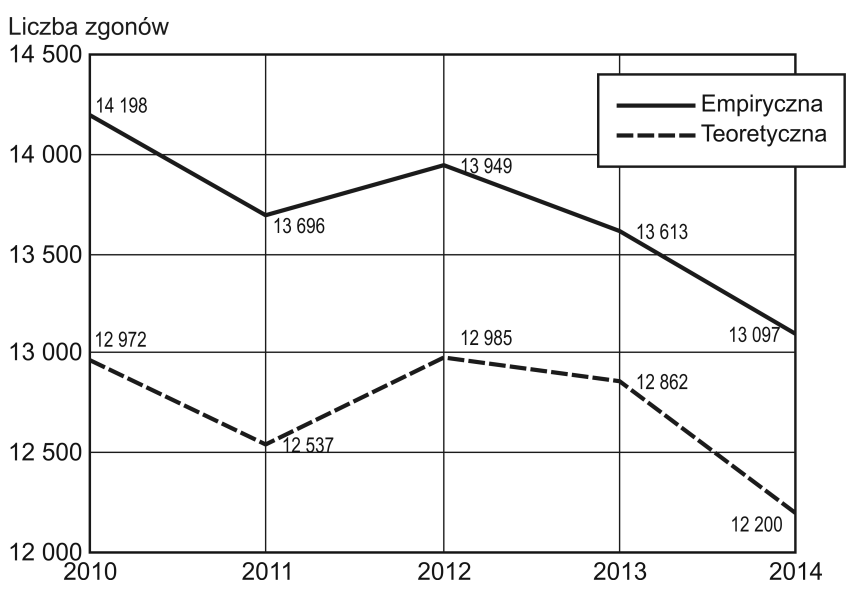

Rys. 10. Teoretyczna i empiryczna liczba zgonów w województwie łódzkim z powodu ChUK w latach 2010-2014 Źródło: opracowanie własne na podstawie danych GUS

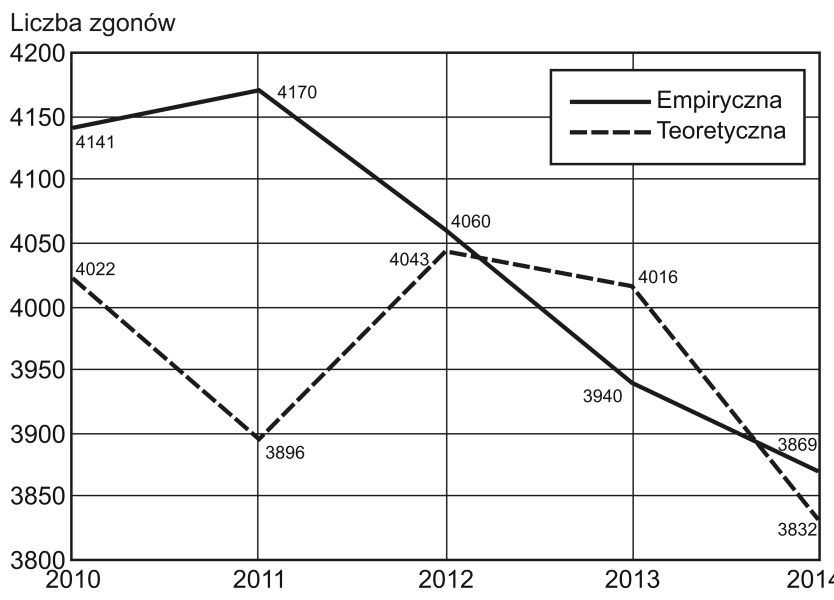

Rys. 11. Teoretyczna i empiryczna liczba zgonów w Łodzi w wyniku ChUK w latach 2010-2014

Źródło: opracowanie własne na podstawie danych GUS

W województwie łódzkim umieralność na ChUK, zarówno "teoretyczna”, jak i „empiryczna” charakteryzowała się tendencją malejącą, czym wpisała się $\mathrm{w}$ ogólny trend obserwowany także $\mathrm{w}$ latach poprzednich (m.in. Pikala, Maniecka-Bryła, Bryła, 2013). Przy tym analiza danych przedstawionych na rys. 10 potwierdza jednak hipotezę pierwszą (H1), że województwo to cechuje nadumieralność w wyniku ChUK (por.: Przybylski, Szukalski, 2015, 
Tab. 2. Prawdopodobieństwa zgonu z powodu ChUK mężczyzn w Polsce według grup wieku w latach 2010-2014

\begin{tabular}{|c|c|c|c|c|c|c|c|c|c|}
\hline \multirow{2}{*}{ Rok } & \multicolumn{10}{|c|}{ Grupa wieku } \\
\cline { 2 - 10 } & $0-4$ & $5-9$ & $10-14$ & $15-19$ & $20-24$ & $25-29$ & $30-34$ & $35-39$ & $40-44$ \\
\hline 2010 & 0,000023 & 0,000007 & 0,000007 & 0,000033 & 0,000050 & 0,000096 & 0,000193 & 0,000390 & 0,000912 \\
\hline 2011 & 0,000010 & 0,000005 & 0,000007 & 0,000035 & 0,000074 & 0,000105 & 0,000180 & 0,000363 & 0,000782 \\
\hline 2012 & 0,000006 & 0,000002 & 0,000011 & 0,000031 & 0,000069 & 0,000098 & 0,000164 & 0,000420 & 0,000811 \\
\hline 2013 & 0,000016 & 0,000003 & 0,000004 & 0,000021 & 0,000051 & 0,000102 & 0,000160 & 0,000345 & 0,000768 \\
\hline 2014 & 0,000007 & 0,000003 & 0,000005 & 0,000032 & 0,000047 & 0,000095 & 0,000177 & 0,000346 & 0,000684 \\
\hline \multirow{8}{*}{ Rok } & \multicolumn{9}{|c|}{ Grupa wieku } \\
\cline { 2 - 12 } & $45-49$ & $50-54$ & $55-59$ & $60-64$ & $65-69$ & $70-74$ & $75-79$ & $80-84$ & $85+$ \\
\hline 2010 & 0,001663 & 0,003193 & 0,005012 & 0,007290 & 0,011975 & 0,018624 & 0,031330 & 0,051975 & 0,102387 \\
\hline 2011 & 0,001559 & 0,002896 & 0,004719 & 0,007030 & 0,010679 & 0,017604 & 0,029183 & 0,049917 & 0,098999 \\
\hline 2012 & 0,001635 & 0,003009 & 0,004773 & 0,007460 & 0,010886 & 0,017921 & 0,029029 & 0,050165 & 0,102860 \\
\hline 2013 & 0,001525 & 0,002863 & 0,004623 & 0,007402 & 0,010646 & 0,017026 & 0,027954 & 0,048936 & 0,099479 \\
\hline 2014 & 0,001362 & 0,002599 & 0,004311 & 0,006754 & 0,009799 & 0,016263 & 0,026012 & 0,045340 & 0,093025 \\
\hline
\end{tabular}

Źródło: obliczenia własne na podstawie danych GUS.

Tab. 3. Prawdopodobieństwa zgonu z powodu ChUK kobiet w Polsce według grup wieku w latach 2010-2014

\begin{tabular}{|l|c|c|c|c|c|c|c|c|c|}
\hline \multirow{2}{*}{ Rok } & \multicolumn{10}{|c|}{ Grupa wieku } \\
\cline { 2 - 10 } & $0-4$ & $5-9$ & $10-14$ & $15-19$ & $20-24$ & $25-29$ & $30-34$ & $35-39$ & $40-44$ \\
\hline 2010 & 0,000031 & 0,000002 & 0,000009 & 0,000014 & 0,000026 & 0,000041 & 0,000055 & 0,000101 & 0,000214 \\
\hline 2011 & 0,000006 & 0,000001 & 0,000006 & 0,000025 & 0,000021 & 0,000036 & 0,000062 & 0,000090 & 0,000228 \\
\hline 2012 & 0,000005 & 0,000003 & 0,000002 & 0,000018 & 0,000020 & 0,000034 & 0,000050 & 0,000098 & 0,000214 \\
\hline 2013 & 0,000006 & 0,000001 & 0,000004 & 0,000020 & 0,000026 & 0,000033 & 0,000053 & 0,000092 & 0,000184 \\
\hline 2014 & 0,000007 & 0,000000 & 0,000005 & 0,000013 & 0,000022 & 0,000034 & 0,000052 & 0,000111 & 0,000184 \\
\hline \multirow{8}{*}{ Rok } & \multicolumn{9}{|c|}{ Grupa wieku } \\
\cline { 2 - 12 } & $45-49$ & $50-54$ & $55-59$ & $60-64$ & $65-69$ & $70-74$ & $75-79$ & $80-84$ & $85+$ \\
\hline 2010 & 0,000401 & 0,000797 & 0,001321 & 0,002342 & 0,004504 & 0,009060 & 0,019593 & 0,042365 & 0,097299 \\
\hline 2011 & 0,000389 & 0,000740 & 0,001220 & 0,002340 & 0,004150 & 0,008435 & 0,018232 & 0,039632 & 0,092270 \\
\hline 2012 & 0,000446 & 0,000805 & 0,001315 & 0,002382 & 0,004220 & 0,008690 & 0,017776 & 0,038548 & 0,095825 \\
\hline 2013 & 0,000407 & 0,000697 & 0,001256 & 0,002353 & 0,004107 & 0,008372 & 0,016927 & 0,037902 & 0,094883 \\
\hline 2014 & 0,000382 & 0,000668 & 0,001180 & 0,002203 & 0,003724 & 0,007687 & 0,015617 & 0,034509 & 0,089197 \\
\hline
\end{tabular}

Źródło: obliczenia własne na podstawie danych GUS.

Tab. 4. Prawdopodobieństwa zgonu z powodu ChUK mężczyzn w miastach w Polsce według grup wieku w latach 2010-2014

\begin{tabular}{|c|c|c|c|c|c|c|c|c|c|}
\hline \multirow{2}{*}{ Rok } & \multicolumn{9}{|c|}{ Grupa wieku } \\
\cline { 2 - 11 } & $0-4$ & $5-9$ & $10-14$ & $15-19$ & $20-24$ & $25-29$ & $30-34$ & $35-39$ & $40-44$ \\
\hline 2010 & 0,000020 & 0,000006 & 0,000007 & 0,000033 & 0,000045 & 0,000091 & 0,000170 & 0,000356 & 0,000894 \\
\hline 2011 & 0,000016 & 0,000004 & 0,000004 & 0,000025 & 0,000075 & 0,000103 & 0,000177 & 0,000334 & 0,000754 \\
\hline 2012 & 0,000008 & 0,000002 & 0,000012 & 0,000036 & 0,000069 & 0,000098 & 0,000160 & 0,000405 & 0,000807 \\
\hline 2013 & 0,000010 & 0,000004 & 0,000006 & 0,000022 & 0,000051 & 0,000101 & 0,000153 & 0,000354 & 0,000758 \\
\hline 2014 & 0,000003 & 0,000003 & 0,000008 & 0,000036 & 0,000045 & 0,000098 & 0,000175 & 0,000344 & 0,000665 \\
\hline \multirow{8}{*}{ Rok } & \multicolumn{9}{|c|}{ Grupa wieku } \\
\cline { 2 - 12 } & $45-49$ & $50-54$ & $55-59$ & $60-64$ & $65-69$ & $70-74$ & $75-79$ & $80-84$ & $85+$ \\
\hline 2010 & 0,001632 & 0,003217 & 0,004849 & 0,007120 & 0,011667 & 0,017441 & 0,029048 & 0,047771 & 0,092000 \\
\hline 2011 & 0,001493 & 0,002865 & 0,004569 & 0,006811 & 0,010267 & 0,016902 & 0,026922 & 0,044580 & 0,088542 \\
\hline 2012 & 0,001670 & 0,002937 & 0,004711 & 0,007205 & 0,010386 & 0,017074 & 0,027161 & 0,045543 & 0,092204 \\
\hline 2013 & 0,001551 & 0,002809 & 0,004585 & 0,007241 & 0,010137 & 0,016008 & 0,026028 & 0,044421 & 0,089336 \\
\hline 2014 & 0,001333 & 0,002607 & 0,004329 & 0,006631 & 0,009477 & 0,015699 & 0,024605 & 0,041507 & 0,084708 \\
\hline
\end{tabular}

Źródło: obliczenia własne na podstawie danych GUS. 
Tab. 5. Prawdopodobieństwa zgonu z powodu ChUK kobiet w miastach w Polsce według grup wieku w latach 2010-2014

\begin{tabular}{|c|c|c|c|c|c|c|c|c|c|}
\hline \multirow{2}{*}{ Rok } & \multicolumn{9}{|c|}{ Grupa wieku } \\
\cline { 2 - 10 } & $0-4$ & $5-9$ & $10-14$ & $15-19$ & $20-24$ & $25-29$ & $30-34$ & $35-39$ & $40-44$ \\
\hline 2010 & 0,000033 & 0,000004 & 0,000014 & 0,000009 & 0,000027 & 0,000043 & 0,000056 & 0,000076 & 0,000217 \\
\hline 2011 & 0,000007 & 0,000000 & 0,000002 & 0,000023 & 0,000020 & 0,000038 & 0,000061 & 0,000090 & 0,000237 \\
\hline 2012 & 0,000003 & 0,000002 & 0,000000 & 0,000022 & 0,00024 & 0,000037 & 0,000048 & 0,000095 & 0,000199 \\
\hline 2013 & 0,000007 & 0,000002 & 0,000006 & 0,000021 & 0,000024 & 0,000032 & 0,000054 & 0,000085 & 0,000189 \\
\hline 2014 & 0,000009 & 0,000000 & 0,000006 & 0,000007 & 0,000025 & 0,000040 & 0,000061 & 0,000120 & 0,000188 \\
\hline \multirow{2}{*}{ Rok } & \multicolumn{8}{|c|}{ Grupa wieku } \\
\cline { 2 - 11 } & $45-49$ & $50-54$ & $55-59$ & $60-64$ & $65-69$ & $70-74$ & $75-79$ & $80-84$ & $85+$ \\
\hline 2010 & 0,000407 & 0,000814 & 0,001280 & 0,002270 & 0,004404 & 0,008613 & 0,018150 & 0,039407 & 0,088091 \\
\hline 2011 & 0,000427 & 0,000742 & 0,001237 & 0,002291 & 0,004048 & 0,007949 & 0,016722 & 0,036090 & 0,086659 \\
\hline 2012 & 0,000468 & 0,000840 & 0,001319 & 0,002374 & 0,004153 & 0,008272 & 0,016524 & 0,035155 & 0,089037 \\
\hline 2013 & 0,000419 & 0,000691 & 0,001269 & 0,002332 & 0,004049 & 0,008097 & 0,015944 & 0,034562 & 0,088655 \\
\hline 2014 & 0,000391 & 0,000691 & 0,001187 & 0,002183 & 0,003664 & 0,007439 & 0,014629 & 0,032008 & 0,083619 \\
\hline
\end{tabular}

Źródło: obliczenia własne na podstawie danych GUS.

\section{DYSKUSJA}

s. 90-93). Dane pokazują, że w ciągu analizowanych pięciu lat (2010-2014), łączna liczba ponadprzeciętnych (w stosunku do ogólnopolskiej średniej) zgonów z powodu tych chorób w wojwództwie łódzkim wyniosła blisko 5 tys., tj. około 1000 osób rocznie.

Analogiczna analiza dla Łodzi nie pozwala już na tak jednoznaczne wnioski, bowiem w latach 2010-2011 Łódź charakteryzowała się wyższą liczbą zgonów z powodu ChUK, niż wynikałoby to $\mathrm{z}$ ogólnopolskich statystyk dla miast, chociaż w latach 2012 i 2014 obie wartości tych danych były do siebie bardzo zbliżone, zaś w 2013 r. umieralność $\mathrm{w}$ wyniku tych chorób byla niższa od wyznaczonej wartości teoretycznej (rys. 11). Niemniej jednak wspólna analiza wszystkich tych danych wskazuje, że w ciągu ostatnich pięciu lat (2010-2014), łączna liczba wartości zgonów z powodu ChUK ponadprzeciętnych ( $w$ stosunku do ogólnopolskiej średniej dla miast) w Łodzi wyniosła 371 osób, co oznacza 75 osób rocznie. Warto $\mathrm{w}$ tym miejscu także odnotować, że od $2011 \mathrm{r}$. umieralność na ChUK w Łodzi cechuje się liniową tendencją malejącą, mimo że obliczone wartości teoretyczne, uwzględniające strukturę demograficzną miasta i ogólnopolskie miejskie statystyki zgonów, nie wykazują trendu analogicznego. Tym samym obserwowane w ostatnich trzech latach zmiany mogą być efektem poprawy sytuacji zdrowotnej mieszkańców Łodzi, ale potwierdzenie wymagałoby pogłębionych analiz epidemiologicznych.
Do głównych czynników ryzyka chorób układu krążenia zalicza się: palenie tytoniu, nadciśnienie tętnicze, zbyt wysoki poziom cholesterolu $(>5,0)$, otyłość, występowanie cukrzycy oraz słabą aktywność fizyczną (por. Drygas 2006, s. 21).

Wyniki badania WOBASZ (Wieloośrodkowe Ogólnopolskie Badanie Stanu Zdrowia Ludności (szerzej: Drygas i in., 2015) w przekroju wojewódzkim nie wskazują na szczególnie niekorzystny obraz przedstawionych czynników w tym województwie, dlatego - mając na uwadze przywołane wyniki - trudno jednoznacznie wiązać ponadprzeciętną umieralność $\mathrm{z}$ powodu ChUK w badanym regionie $\mathrm{z}$ niewłaściwymi postawami prozdrowotnymi mieszkańców (por. Polakowska i in., 20053; Tykarski i in., 2005; Drygas i in., 2005; Biela i in., 2005; Pająk i in., 2005; Społeczne nierówności..., 2012).

Z drugiej strony realizowane są przez GUS badania stanu zdrowia ludności, polegające na dokonaniu samooceny jego stanu. Stwierdzono, że odpowiedzi "dobre” lub „bardzo dobre” są najrzadziej udzielane przez mieszkańców województwa łódzkiego (dane ogólnokrajowe informują, że dobrym lub bardzo dobrym stanem zdrowia cechuje się 67,4\% mieszkańców, zaś w województwie łódzkim 61,8\%). Co więcej, podczas gdy co 10. Polak ocenia stan swojego zdrowia jako „zły" lub „bardzo zły", w województwie łódzkim takie poczucie deklaruje $14 \%$, co w przekroju wojewódzkim stanowi w Polsce wartość najwyższą (szerzej: Stan zdrowia..., 2016). Niekorzystnie wypada województwo 
łódzkie także pod względem częstości występowania tzw. dolegliwości przewlekłych. W skali ogólnokrajowej odnotowuje się je u nieco ponad połowy Polaków (54\%), najczęściej zaś występują w województwach łódzkim i śląskim - u 60\% ludności (Stan zdrowia..., 2016). Łódzkie Regionalne Centrum Polityki Społecznej potwierdza też relatywnie zły stan zdrowia mieszkańców łódzkiego, wskazując na: najkrótsze w kraju przeciętne trwanie życia kobiet i mężczyzn, drugie miejsce $\mathrm{w}$ kraju pod względem występowania chorób cywilizacyjnych, prowadzenie niezdrowego stylu życia przez mieszkańców, niską ich świadomość zdrowotną oraz najwyższy w kraju wskaźnik zachorowalności na gruźlicę (Plan przewidywania..., 2013).

\section{PODSUMOWANIE}

Województwo łódzkie charakteryzuje się nadumieralnością z powodu chorób układu krążenia, sięgającą średniorocznie blisko 1000 osób, przy tym ukazana niekorzystna sytuacja epidemiologiczna dotycząca umieralności z powodu ChUK w tym regionie utrzymuje się już od kilkunastu lat (por. Maniecka-Bryła, Bryła, Drygas, 2005). Chociaż dostępne wyniki badania WOBASZ nie potwierdzają $\mathrm{w}$ omawianym regionie szczególnie wysokich wartości parametrów będących czynnikami ryzyka ChUK, to już statystyki związane z ogólnym stanem zdrowia mieszkańców (samoocena), częstością występowania chorób przewlekłych oraz z innymi wskaźnikami demograficzno-epidemiologicznymi (przeciętne dalsze trwanie życia, zachorowalność na ChUK, niska świadomość zdrowotna) kształtują się dla mieszkańców województwa niekorzystnie. Tym samym widać, że niezadowalających statystyk umieralności z powodu ChUK nie można wiązać jedynie $\mathrm{z}$ niekorzystną $\mathrm{z}$ punktu widzenia tych chorób strukturą demograficzną.

Lepsza sytuacja jest w samej Łodzi, bowiem w ciągu ostatnich trzech lat, za które dysponujemy danymi statystycznymi, prawdopodobieństwo zgonu w tym mieście w wyniku ChUK (przy uwzględnieniu czynnika płci i wieku) jest zbliżone do ogólnopolskiej średniej dla miast, a niekiedy nawet jest od niej niższe. Zatem obserwowana $w$ Łodzi wysoka liczba zgonów z powodu chorób układu krążenia (m.in. względem innych wielkich miast w Polsce) wydaje się wynikać bardziej z niekorzystnej struktury demograficznej niż z przyczyn związanych ze stanem zdrowia.

\section{PRZYPISY}

${ }^{1}$ Osobną kwestią jest rzetelność polskich danych raportujących zgony według przyczyn (szerzej: Cierniak-Piotrowska, Marciniak, Stańczak, 2015).

2 Zgodnie $\mathrm{z}$ założeniami, $\mathrm{w}$ analizach dla województwa łódzkiego za TER przyjmowano Polskę, zaś dla Łodzi - miasta $w$ Polsce.

${ }^{3}$ Przytaczany w przywołanych publikacjach projekt WOBASZ stanowi standard badań epidemiologicznych w Polsce, choć niestety pochodzi z badania przeprowadzonego ponad 10 lat temu. Niestety, wyniki badania WOBASZ II przeprowadzonego w latach 2013-2014 nie zostały jeszcze opublikowane w przekroju wojewódzkim. Z drugiej strony przejawianie niewłaściwych zachowań prozdrowotnych może skutkować przedwczesnym zgonem osób, zazwyczaj jednak z pewnym opóźnieniem w stosunku do stanu wystąpienia, dlatego - zdaniem autora - porównanie $\mathrm{w}$ województwach kształtowania się czynników ryzyka chorób układu krążenia, choć odnosi się do sytuacji oddalonej czasowo, ciągle stanowi wartościowe informacje dla prowadzenia analiz umieralności.

\section{BIBLIOGRAFIA}

Biela, U., Pająk, A., Kaczmarczyk-Chałas, K., Głuszek, J., Tendera, M., Waśkiewicz, A., Kurjata, P., Wyrzykowski, B. (2005). Częstość występowania nadwagi i otyłości u kobiet i mężczyzn w wieku 20-74 lat. Wyniki WOBASZ. Kardiologia Polska, 63, Supl. IV.

Cicha-Mikołajczyk, A., Piotrowski, W., Kurjata, P., Piwońska, A., Polakowska, M. (2016). Zmiany umieralności z powodu chorób uktadu krażenia w latach 2010-2014 w Polsce, IX Konferencja Naukowa Sekcji Prewencji i Epidemiologii Polskiego Towarzystwa Kardiologicznego "Kardiologia Prewencyjna 2016 - wytyczne, wątpliwości, gorące tematy", http://2016.kardiologiaprewen cyjna.eu/program (data dostępu: 6.06.2017).

Cierniak-Piotrowska, M., Marciniak, G., Stańczak, J. (2015). Statystyka zgonów i umieralności z powodu chorób układu krążenia. W: Z. Strzelecki, J. Szymborski (red.), Zachorowalność $i$ umieralność na choroby układu krążenia a sytuacja demograficzna Polski. Rządowa Rada Ludnościowa, http://bip stat.gov.pl/organizacja-statystyki-publicznej/rzadowa-radaludnosciowa/publikacje-rzadowej-rady-ludnosciowej/(data dostępu: 6.06.2017)

Drygas, W. (2006). Profilaktyka chorób serca i naczyń, http://slideplayer.pl/slide/405189/ (data dostępu: 2.06.2017).

Drygas, W., Bielecki, W., Kozakiewicz, K., Pająk, A., Piotrowski, W., Tykarski, A., Wyrzykowski, B., Zdrojewski, T. (2015). Wieloośrodkowe Ogólnopolskie Badanie Stanu Zdrowia Ludności - WOBASZ. W: G. Kopeć, P. Jankowski, A. Pająk, W. Drygas (red.), Epidemiologia i prewencja chorób układu krążenia (s. 41-56). Kraków: Medycyna Praktyczna.

Drygas, W., Kwaśniewska, M., Szcześniewska, D., Kozakiewicz, K., Głuszek, J., Wiercińska, E., Wyrzykowski, B., Kurjata, P. (2005). Ocena poziomu aktywności fizycznej dorosłej populacji Polski. Wyniki programu WOBASZ. Kardiologia Polska, 63, Supl. IV.

Drygas, W., Słońska, Z. (2015). Polkard Media „Pamiętaj o sercu". W: G. Kopcia, P. Jankowski, A. Pająk, W. Drygas (red.), Epidemiologia i prewencja chorób układu krążenia (s. 123-128). Kraków: Medycyna Praktyczna.

Kałuża-Kopias, D. (2015). Migracje w województwie łódzkim W: P. Szukalski (red.), Procesy demograficzne w województwie 
tódzkim w XXI wieku (s. 109-144). Łódź: Wyd. Uniwersytetu Łódzkiego.

Kałuża-Kopias, D. (2016). Migracje w województwie łódzkim. Studia Ekonomiczne, Zeszyty Naukowe Uniwersytetu Ekonomicznego w Katowicach, 290, s. 187-197.

Kałuża-Kopias, D. (2017). Migracje w województwie łódzkim. W: J. Hrynkiewicz, A. Potrykowska (red.), Sytuacja demograficzna województwa łódzkiego jako wyzwanie dla polityki spotecznej $i$ gospodarczej (s. 138-157). Warszawa: Rządowa Rada Ludnościowa, GUS.

Kwaśniewska, M., Drygas, W. (2015). Program Profilaktyki i Wczesnego Wykrywania Chorób Układu Krążenia Narodowego Funduszu Zdrowia. W: G. Kopcia, P. Jankowski, A. Pająk, W. Drygas (red.). Epidemiologia i prewencja chorób układu krążenia (s. 133-140). Kraków: Medycyna Praktyczna.

Maniecka-Bryła, I., Bryła, M., Drygas, W. (2005). Sytuacja epidemiologiczna chorób układu krążenia w województwie łódzkim na tle sytuacji epidemiologicznej w Polsce na początku XXI wieku. Przegląd Epidemiologiczny, 59, s. 923-932.

Pająk, A., Jankowski, P., Wolfshaut-Wolak, R. (2015). Program EuroAction. W: G. Kopcia, P. Jankowski, A. Pająk, W. Drygas (red.), Epidemiologia i prewencja chorób układu krążenia (s. 157-162). Kraków: Medycyna Praktyczna.

Pająk, A., Wiercińska, E., Polakowska, M., Kozakiewicz, K., Kaczmarczyk-Chałas, K., Tykarski, A., Gaździk, D., Zdrojewski, T. (2005). Rozpowszechnienie dyslipidemii u mężczyzn i kobiet w wieku 20-74 lat w Polsce. Wyniki badania WOBASZ. Kardiologia Polska, 63, Supl. IV.

Pikala, M., Maniecka-Bryła, I. (2013). Ocena zmian w umieralności w województwie łódzkim na tle Polski i Unii Europejskiej. Hygeia Public Health, 48 (4), s. 520-525.

Pikala, M., Maniecka-Bryła, I., Bryła, M. (2013). Trendy umieralności z powodu najczęstszych przyczyn zgonów w województwie łódzkim w latach 1999-2008 - analiza joinpoint regression. Hygeia Public Health, 48 (1), s. 28-34.

Plan przeciwdziałania depopulacji w województwie tódzkim. (2013). Łódź: Regionalne Centrum Polityki Społecznej.
Polakowska, M., Piotrowski, W., Tykarski, A., Drygas, W., Wyrzykowski, B., Pająk, A., Kozakiewicz, A., Rywik, S. (2005). Nałóg palenia tytoniu w populacji polskiej. Wyniki programu WOBASZ. Kardiologia Polska, 63, Supl. IV.

Przybylski, M., Szukalski, P. (2015). Stan zdrowia mieszkańców województwa łódzkiego. W: P. Szukalski (red.), Procesy demograficzne w województwie łódzkim w XXI wieku. Łódź: Wyd. Uniwersytetu Łódzkiego.

Społeczne nierówności w zdrowiu w Polsce. (2012). WHO, Regional Office for Europe.

Stan zdrowia ludności Polski w 2014 r. (2016). Warszawa: GUS, Zakład Wydawnictw Statystycznych.

Szukalski, P. (2012). Sytuacja demograficzna Łodzi. Łódź: Wyd. Biblioteka.

Szukalski, P. (2015). Przemiany zachowań rozrodczych w województwie łódzkim. W: P. Szukalski (red.), Procesy demograficzne w województwie tódzkim w XXI wieku. Łódź: Wyd. Uniwersytetu Łódzkiego.

Tykarski, A., Posadzy-Małaczyńska, A., Wyrzykowski, B., Kwaśniewska, M., Pająk, A., Kozakiewicz, K., Rywik, S., Broda, G. (2005). Rozpowszechnienie nadciśnienia tętniczego oraz skuteczność jego leczenia u dorosłych mieszkańców naszego kraju. Wyniki programu WOBASZ. Kardiologia Polska, 63, Supl. IV.

Wojtyniak, B., Stokwiszewski, J. (2015). Trendy czasowe umieralności ogółem oraz z powodu głównych przyczyn: chorób układu krążenia, nowotworów złośliwych oraz przyczyn zewnętrznych w Polsce na tle sytuacji w UE15. Zdrowie Publiczne $i$ Zarzadzanie, 13 (4), s. 316-327.

Wojtyniak, B., Zdrojewski, T. (2015). Umieralność z powodu chorób układu krążenia w Polsce - analiza zmian w latach 1999-2013. W: G. Kopcia, P. Jankowski A. Pająk, W. Drygas (red.), Epidemiologia i prewencja chorób uktadu krążenia (s. 29-40). Kraków: Medycyna Praktyczna.

http://www.nierownosci.mz.gov.pl/wp-content/uploads/sites /6/2014/07/Spoleczne-nierownosci-w-zdrowiu-w-Polsce.pdf (data dostępu: 2.06.2017). 